\title{
Correction to: Abstracts from the 5th International Porto Congress of Multiple Sclerosis
}

Maria José Sá

Published online: November 4, 2019

(C) The Author(s) 2019

Correction to: Neurol Ther (2019) 8 (Suppl 1):S1-S31

https://doi.org/10.1007/s40120-019-0135-2

The given name of one of the authors was incorrectly published as Vera in abstract EPIII028 “Anti-MOG Antibody-Positive Isolated Longitudinally Extensive Transverse Myelitis". The correct name should read as follows:

\section{EPIII028}

Anti-MOG Antibody-Positive Isolated Longitudinally Extensive Transverse Myelitis

Adilson Cláudio Marcolino; Verónica Cabreira; Teresa Mendonça; Cátia Figueiredo; Goreti Nadais.

M. J. Sá

Faculty of Health Sciences, University Fernando Pessoa, Rua Carlos da Maia, Porto, Portugal

Open Access. This article is distributed under the terms of the Creative Commons Attribution-NonCommercial 4.0 International License (http://creativecommons.org/licenses/ by-nc/4.0/), which permits any noncommercial use, distribution, and reproduction in any medium, provided you give appropriate credit to the original author(s) and the source, provide a link to the Creative Commons license, and indicate if changes were made. 